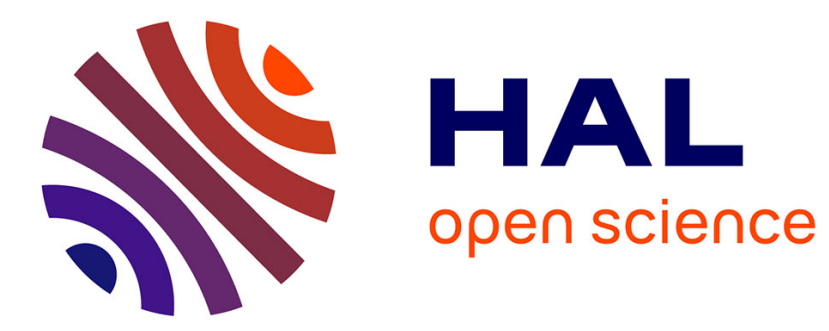

\title{
Colonial Minds, Postcolonial Places
}

Mustafa Dikeç

\section{To cite this version:}

Mustafa Dikeç. Colonial Minds, Postcolonial Places. Antipode, 2010, 10.1111/j.14678330.2010.00775.x . hal-01274394

\section{HAL Id: hal-01274394 \\ https: / hal-enpc.archives-ouvertes.fr/hal-01274394}

Submitted on 15 Feb 2016

HAL is a multi-disciplinary open access archive for the deposit and dissemination of scientific research documents, whether they are published or not. The documents may come from teaching and research institutions in France or abroad, or from public or private research centers.
L'archive ouverte pluridisciplinaire HAL, est destinée au dépôt et à la diffusion de documents scientifiques de niveau recherche, publiés ou non, émanant des établissements d'enseignement et de recherche français ou étrangers, des laboratoires publics ou privés. 


\title{
Colonial Minds, Postcolonial Places
}

\author{
Mustafa Dikeç \\ Department of Geography, Royal Holloway, University of London, \\ London, UK; \\ m.dikec@rhul.ac.uk
}

I have felt moved to write this piece for two reasons. First, the episode I will recount below resonates strongly with my experience and that of other non-European colleagues (those I have been discussing with, at least) regarding the politics of academic knowledge production in Western academic contexts. Second, it exemplifies what in my view is a rather problematic understanding of "Eurocentrism" and "theory", reducing the former to an unproductive polemical register, and confusing the latter with a user's manual. The episode consists of me being called "Eurocentric" in an academic workshop, although this piece is in no way intended as a response to my accusers. Rather, it is written in the spirit of addressing the issues identified above, which I take to be of political, theoretical and pedagogic significance.

What, then, was my sin to deserve this academic and political kiss of death? I was surprised-stunned even-especially because I had taken good care to start with a disclaimer that my paper was informed by the French context and inspired by a particular French thinker. Since the previous day of the workshop had seen numerous remarks of the type "Yes, but this doesn't work in Sri Lanka!" (there was a contingent of anthropologists and development geographers with ongoing research projects there), I was careful, running the risk of sounding defensive, to also emphasize that my paper offered one among many possible ways of thinking about the relationship between space and politics, one of the workshop themes. Alas, it didn't work in Sri Lanka! Although I tried to explain that my paper was neither inspired by nor responding to the situation in Sri Lanka, I, the only non-European present, ended up being the only Eurocentric of the whole workshop. The problem, according to my interlocutors, was that my alleged "model" (a term I had deliberately avoided) either "did not work in" or "did not apply to" Sri Lanka (Pakistan, if I remember correctly, was also mentioned).

It is this kind of use of the term that I find unproductive and problematic. Based on a strictly geographical or even cartographical 
imagery, this understanding makes it all too easy to stick the Eurocentric label, and hardly goes, in my view, beyond mere name-calling (although I suspect the discursive effects of the deployment of the Eurocentric label are not unrelated to the construction of disciplinary regimes, claims to authenticity, and professional identity and authority). Ironically, however, this understanding and use of the term only exacerbates some of the difficulties associated with Eurocentrism as a cultural, epistemological and political problem as it reproduces the premises upon which Eurocentric thought (and practice) is based. Wallerstein (1997:1) had already warned against this when he wrote "if we are not careful, in the guise of trying to fight it, we may in fact criticize Eurocentrism using Eurocentric premises and thereby reinforce its hold on the community of scholars". In the present case, this is evident in the immediate intellectual reflex that sees theory or theoretical statements as a "model" to be "applied", regardless of the fact that they may have been inspired by and responding to particular contexts. To paraphrase Wallerstein, this view of theory seems to be very Eurocentric in its antiEurocentrism as it takes theory produced in Europe as a "model" to be "applied" to other, in this case postcolonial, contexts, only to find that it (very unsurprisingly) doesn't "work" there.

This sort of Eurocentric anti-Eurocentrism not only fails to challenge established Eurocentric knowledge structures and practices of academic knowledge production, but effectively reproduces them. Many of the other participants in the workshop had also drawn upon the works of Western European thinkers (including Kant, Habermas, Schmitt, Simmel, Weber, Deleuze and Guattari, Foucault and Rancière), occasionally making universal theoretical statements, but none deserved the Eurocentric label. I couldn't help thinking that I must have done something I wasn't supposed to do, or have not done the thing I was supposed to.

This brought back memories of my postgraduate years and discussions with fellow doctoral students, many of whom, like myself, were studying abroad. One of the recurrent issues that used to come up was the choice of dissertation topics, and I remember some complaining about being encouraged by their supervisors to work on immigrationrelated issues, or at least on something that had to do with their home countries. That wasn't my experience, although something slightly similar happened when I went to Paris to work on French urban policy. In my conversations with many French doctoral students and scholars, there was almost always an expression of surprise, if not scepticism, when I told them that "no, my research wasn't about Turkish immigrants in Paris, but about the spatial politics of French urban policy". I was amused, however, to find out that their research, as it happened to be in many cases, involved "fieldwork" in the former colonies of France, 
which, of course, was perfectly normal. I still find myself, if more rarely now, having to justify my interest in space and politics, and not immigration policies or religion in France, which, I suppose, my name suggests that I should be doing.

This brings me to the issue of "fieldwork" and the accompanying selfrighteousness that comes from being "in the field" (a colonial reflex of sorts?). And not just any field; fieldwork in postcolonial contexts, the workshop suggested, was proudly worn as a badge of honour. "Just came back from fieldwork in Sri Lanka" was uttered as frequently as that polite forerunner to a question after one's presentation "Your paper was very interesting, but...." And of course, whatever the paper was about didn't "work" in Sri Lanka! I couldn't help but wonder if my work in France, in the banlieues or in the dusty spaces of archives, would have received the same kind of respect and generated a similar level of legitimacy. But somehow I felt that a statement like "Just came back from fieldwork in Paris" would have done little to help my case. Some contexts (a town in a former colony, a tsunami affected village, a slum in a "developing country", a tea plantation ...) are unhesitatingly called "the field" whereas others, at the very best, still have to negotiate their way through legitimacy. Such a proud display of the "fieldwork" badge of honour seems to me problematic in that it also betrays antiEurocentric positions as it essentially intensifies one of the hallmark consequences of Eurocentric thinking. It not only does "little to refute that sense of a world cartographically bifurcated into a theory rich west and the rest of the world construed more or less as field" (Jazeel forthcoming:5), but effectively reproduces it.

There are sound reasons for criticizing and destabilizing Eurocentric knowledge structures and practices, but any such critique, if it is to have any critical purchase, must go beyond a parochial "geography of ideas" (Jazeel 2007) and conceive of Eurocentrism as a cultural, epistemological and political problem that runs deep in established knowledge structures, including practices of academic knowledge production with its conventions and prejudices. Along the way, it would also help to stop using the term for easy name-calling. As Mufti (2005:473) argues, the problem of Eurocentrism is all "too important to be left in the polemical register that seems to have become its fate in contemporary discussion".

Apart from the two forms of Eurocentric anti-Eurocentrism outlined above, there is, I suspect, also a fundamental problem here that relates to the issue of theory. Theories are not descriptions; the (alleged) mimetic function of theory constantly fails because the accurate portrayal of "reality" is not theory's vocation. Theories are not "models" to be "applied" either. As Wendy Brown has put it, theory is "a meaningmaking enterprise" that, first, depicts a world which both is and is 
not yet, and second, eludes any demand for applicability. This is what makes theory different and distinct from a model, or a formula, or a user's manual.

Thus, theory is never "accurate" or "wrong"; it is only more or less illuminating, more or less provocative, more or less of an incitement to thought, imagination, desire, possibilities for renewal... [T]heory is a sense-making enterprise of that which often makes no sense, of that which may be inchoate, unsystematized, inarticulate. It gives presence to what may have a liminal, evanescent, or ghostly existence. Thus, theory has limited kinship with the project of accurate representation; rather its value lies in the production of a new representation, in the production of coherence and meaning that it does not find lying on the ground but that, rather, it forthrightly fashions (Brown 2002: 574).

This is why theory can afford to make universal statements-not with a pretention or even an aim to an accurate description of the sensible world, but rather with a belief in a possible world of sense and action inspired, affected, informed, stimulated, even challenged, by this world in an attempt to re-present alternative ways of making sense of the world (which, of course, doesn't imply that theories are detached from "the real world out there"). Problems arise when such statements are taken to be or used as universalizing statements that should unproblematically apply to all things and all places. The universal statements of theory ("European" or otherwise) and the parochialism of Eurocentric thinking are not one and the same thing. It seems to me crucial to abandon such user's manual readings of theory and to learn to avoid interpreting universal statements of theory as necessarily universalizing ones that make one mode of thinking normal and normative across time and space. For the user's manual reading of theory, coupled with prejudices about what counts as a "proper" research topic for whom and what counts as a "proper field" and the sort of self-righteousness that accompanies "fieldwork"- the two forms of Eurocentric anti-Eurocentrism outlined above, shuts off the possibility of any meaningful, engaging and generous dialogue between people who just happen to be interested in different things, places, issues or approaches. "Theory's most important political offering", Brown (2002:574) writes, is in the "opening of a breathing space between the world of common meanings and the world of alternative ones, a space of potential renewal for thought, desire, and action". Contesting the compartmentalization and policing of this dynamic space, resisting its colonization, is of utmost political significance for those who have not given up on the possibilities for alternative ways of saying, being, and doing - even for those that are seen as out of place, doing things they are not supposed to do, or not doing the things they are supposed to. 


\section{Acknowledgements}

I am grateful to Nigel Clark, David Featherstone, Yasmin Gunaratnam, Claire Hancock and Tariq Jazeel for their generous comments.

\section{References}

Brown W (2002) At the edge. Political Theory 30(4):556-576

Jazeel T (2007) Awkward geographies: Spatializing academic responsibility, encountering Sri Lanka. Singapore Journal of Tropical Geography 28(3):287-299

Jazeel $\mathrm{T}$ (forthcoming) The geography of theory: Knowledge, politics and the postcolonial present. In A Teverson and S Upstone (eds) Postcolonial Spaces: The Politics of Place in Contemporary Culture. Basingstoke: Palgrave Macmillan

Mufti A (2005) Global comparativism. Critical Inquiry 31(2):472-489

Wallerstein I (1997) Eurocentrism and its avatars: The dilemmas of social science. Keynote address at ISA East Asian Regional Colloquium, "The Future of Sociology in East Asia", 22-23 November, Seoul, Korea 